\title{
GENERALIZED OPIAL-TYPE INEQUALITIES FOR DIFFERENTIAL AND INTEGRAL OPERATORS WITH SPECIAL KERNELS IN FRACTIONAL CALCULUS
}

\section{G. FARID, J. PEČARIĆ AND Ž. TOMOVSKI}

Abstract. In this paper we give Opial-type inequalities for two functions and multiple Opialtype inequalities by using generalized fractional differential and integral operators with special kernels. Also, we deduce some results that already have been proved in $[9,10]$.

Mathematics subject classification (2010): 26A33, 26D15, 33E12. function.

Keywords and phrases: Opial-type inequality, fractional integral, fractional derivative, Mittag-Leffler

\section{REFERENCES}

[1] R. P. Agarwal and P. Y. H. Pang, Opial Inequalities with Applications in Differential and Difference Equations, Kluwer Academic Publishers, Dordrecht, Boston, London 1995.

[2] G. A. Anastassiou, Advanced inequalities, 11, World Scientific, 2011.

[3] M. Andrić, A. BARbir, G. FARID And J. PeČArić, More on certain Opial-type inequality for fractional derivatives, Nonlinear Funct. Anal. Appl., 19, 4 (2014), 565-583.

[4] M. Andrić, A. BARbir, G. Farid And J. PeČArić, Opial-type inequality due to Agarwal-Pang and fractional differential inequalities, Integral Transforms Spec. Funct., 25, 4 (2014).

[5] M. Andrić, J. PeČArić And I. Perić, General Opial-type inequalities for the Canavati fractional derivative, Ann. Funct. Anal. 4 (2013), 149-162.

[6] M. Andrić, J. PeČArić And I. Perić, An Opial type inequality for fractional derivatives of two functions, Fractional Differ. Calc. 3, 1 (2013), 55-68.

[7] A. A. Kilbas, M. SAigo And R. K. SAXEna, Generalized Mittag-Leffler function and generalized fractional calculus operators, Integral Transforms Spec. Funct. 15, 1 (2004) 31-49.

[8] R. Garra, R. Gorenflo, F. Politto And Ž. Tomovski, Hilfer-Prabhakar Derivatives and some Applications, Appl. Math. Comput. Vol. 242 (2014), 576-589.

[9] S. IQbal, J. PeČARIĆ AND M. SAmraiz, Opial type inequalities for two functions with general kernels and applications, J. Math. Ineq. Vol. 8, 4 (2014), 757-775.

[10] S. IQBAL, J. PeČARIĆ AND M. SAMraiz, Multiple Opial type inequalities for general kernels with applications, J. Math. Ineq. Vol. 9, 2 (2015), 381-396.

[11] A. A. Kilbas, H. M. Srivastava and J. J. Trujillo, Theory and Applications of fractional derivatial Equations, North-Holland Mathematics Studies, 204, Elsevier, New York-London, 2006.

[12] K. Miller AND B. Ross, An introduction to the fractional calculus and fractional differential Equations, John Wiley and Sons Inc., New York, 1993.

[13] K. Oldham And J. Spanier, The fractional calculus, Academic Press, New York-London, 1974.

[14] Z. Opial, Sur une inégalité, Ann. Polon. Math., 8 (1960), 29-32.

[15] T. R. PRABHAKAR, A singular integral equation with a generalized Mittag-Leffler function in the kernel, Yokohama Math. J. 19 (1971) 7-15.

[16] T. O. SAlim And A. W. FARAJ, A Generalization of Mittag-Leffler function and integral operator associated with fractional calculus, J. Fract. Calc. Appl. 3, 5 (2012), 1-13.

[17] H. M. SRIVASTAVA AND Ž. TOMOVSKI, Fractional calculus with an integral operator containing generalized Mittag-Leffler function in the kernal, Appl. Math. Comput. 211 (2009), 198-210. 
[18] Ž. Tomovski, R. Hilfer AND H. M. SRIVASTAVA, Fractional and operational calculus with generalized fractional derivative operators and Mittag-Leffler functions, Integral Transforms Spec. Funct. 21, 11 (2010), 797-814.

[19] Ž. TOMOVSKI, T. PogAnY AND H. M. SRIVASTAVA, Laplace type integral expressions for a certain three-parameter family of generalized Mittag-Leffler functions with applications involving complete monotonicity, J. Franklin Institute, 351 (2014), 5437-5454. 